\title{
Impact of potassium fertilizers with different active ingredients and dosages on potato yield in experiments in the Nyírség region
}

\author{
Kruppa, J. \& Zsom, E. \\ University of Debrecen Centre of Agricultural Sciences Faculty of Agriculture \\ Department of Crop Production and Applied Ecology
}

\begin{abstract}
Summary: A five-year experiment was carried out in the Nyirség on its characteristic soil type, brown forest soil to investigate the impact of three types of potassium fertilizers (potassium chloride, potassium sulfate and Patentkáli) in three different dosages $\left(80,160,240 \mathrm{~kg} / \mathrm{ha} \mathrm{K}_{2} \mathrm{O}\right)$, under non-irrigated conditions applying the same dosages of N, P in all treatments (the applied amount was different between years) in 10 treatments including the control on $50 \mathrm{~m}^{2}$-parcels with 3 or 4 replicates. The test plant was cultivar Desirée, Kondor, Agria and Pannónia in 1998 and 2000,2001, 2002 and 2003, respectively. The obtained yields were analyzed by an analysis of variance. Based on the five-year results, the highest yields on the acidic sandy and sandy loam soils were obtained in the treatments with $530-800 \mathrm{~kg} / \mathrm{ha}$ Patentkáli containing $30 \%$ of $\mathrm{K}$ and $10 \%$ of magnesium active ingredients in addition to the same amounts of $\mathrm{N}$ and $\mathrm{P}$ applications. The dosage of $530 \mathrm{~kg} / \mathrm{ha}$ Patentkáli contains $160 \mathrm{~kg} / \mathrm{ha} \mathrm{K}+53 \mathrm{~kg} / \mathrm{ha} \mathrm{Mg}$ active ingredients, while the dosage of $800 \mathrm{~kg} / \mathrm{ha}$ Patentkáli contains $240 \mathrm{~kg} / \mathrm{ha} \mathrm{K}+80 \mathrm{~kg} / \mathrm{ha}$ $\mathrm{Mg}$ active ingredients. It can be concluded that the potassium chloride fertilizer $(\mathrm{KCl})$ was the least effective as regards yields and Patentkáli proved to be the most effective fertilizer, it had higher yields than even those of potassium sulfate, the difference in the $160 \mathrm{~kg} / \mathrm{ha}$ treatments was $17.7 \%$, which was a significant difference. Based on the results of the multi-year experiment, we recommend to apply $530 \mathrm{~kg} / \mathrm{ha}$ Patentkáli fertilizer $(160 \mathrm{~kg} / \mathrm{ha} \mathrm{K}+53 \mathrm{~kg} / \mathrm{ha} \mathrm{Mg}$ active ingredients) for the fertilization in potato under non-irrigated conditions on the acidic sandy and sandy loam forest soils of the Nyirseg, which proved to be the most effective treatment and with which we could obtain 30 t/ha yield in the average of the years (with the simultaneous application of $\mathrm{N}$ and $\mathrm{P}$ ).
\end{abstract}

Key words: potato, irrigation, potato cultivars.

\section{Introduction}

The level of Hungarian potato production is low. Hungary should prepare for the increasing tough competition in the EU markets. In order to maintain at least our domestic market position, the level of production has to be improved. To achieve this, quality should be improved in addition to increasing yields and decreasing prime costs. Therefore, we should obtain a better knowledge of the ecological, biological and production factors affecting the quality of potato. The plant can only realize its genetic potential in an optimum tuber yield and in maximum quality, if the necessary nutrients, water and temperature are available during the vegetation period in harmony with the plant's requirements. The objective of the present study was to determine the optimum amount and form of potassium fertilizers in a nonirrigated experiment under the agroecological conditions of the Nyirség region. Among nutrients, nitrogen and potassium influence primarily amount and quality, respectively. Plants with a proper potassium supply have better cold resistance. Potato requires a small amount of phosphorus as compared to other plants (Terbe, 2000).

Pocsai (2001) emphasized the following points: The experiments verify an excellent fertilizer reaction in potato, however, the cultivar effect is stronger than the fertilizer treatment effect. A precondition of high yields is the shared $\mathrm{N}$ fertilization and the application of $\mathrm{N}$ during the vegetation period, even the highest dosage of phosphorus (198 kg/ha) could not influence yields significantly, however, it increased the number of tubers, thereby changing the size distribution of the tubers. When selecting the potassium fertilizer, the planned use of potato should be considered. Sulfate-type potassium fertilizers are preferable when the utilization requires a high starch content (potato for industrial use, chips, pommes-frites), since sulfate has a less disadvantageous effect on starch formation than chlorine. The results of the experiments have the following indications:

- in potato production, potassium supply has a strong effect on yield quality and quantity,

- potassium improves the storability of potato and prevents after-cooking darkening,

- the reduction in starch is smaller in the case of sulfate-type fertilizers than for chloride-type ones (Glas et al., 1997).

Raw coloration and after-cooking darkening are such quality measures which have an important role in the case of table potato and tubers that have to be stored for a longer period before use. Proper potassium supply reduces the raw coloration. At the same time, after-cooking darkening is also 
Table 1. Dosages of nitrogen and phosphorus fertilizers during the experiment

\begin{tabular}{|l|l|l|l|l|l|l|}
\hline $\begin{array}{l}\text { Active } \\
\text { ingre- } \\
\text { dient }\end{array}$ & $\begin{array}{l}\mathbf{1 9 9 8} \\
\mathbf{k g} / \mathbf{h a}\end{array}$ & $\begin{array}{l}\mathbf{2 0 0 0} \\
\mathbf{k g} / \mathbf{h a}\end{array}$ & $\begin{array}{l}\mathbf{2 0 0 1} \\
\mathbf{k g} / \mathbf{h a}\end{array}$ & $\begin{array}{l}\mathbf{2 0 0 2} \\
\mathbf{k g} / \mathbf{h a}\end{array}$ & $\begin{array}{l}\mathbf{2 0 0 3} \\
\mathbf{k g} / \mathbf{h a}\end{array}$ & $\begin{array}{l}\text { Name of the } \\
\text { fertilizer }\end{array}$ \\
\hline $\mathrm{N}$ & 280 & 150 & 204 & 170 & 80 & Ammonium nitrate $34 \%$ \\
\hline $\mathrm{P}_{2} \mathrm{O}_{5}$ & 152 & 90 & 108 & 108 & 40 & Szuperfoszfát $18 \%$ \\
\hline
\end{tabular}

$10-35 \%+10-20 \%$ can be expected. Yield was not significantly influenced by the form of the potassium fertilizer (chloride or sulfate). Potassium fertilization increased the size of the tubers. Coloration of tubers (raw) from parcels treated with the highest dosage of potassium (240 kg/ha active ingredient) was the smallest. By applying both nutrients, the amount and quality of yield can be improved profitably (Kruppa et al., 1997).

Table 2. Dosages of potassium and magnesium fertilizers per parcel and per hectare

\begin{tabular}{|c|c|c|c|c|c|c|c|c|c|c|c|c|c|c|}
\hline \multirow{2}{*}{$\begin{array}{l}\text { Treat- } \\
\text { ment }\end{array}$} & \multicolumn{2}{|c|}{$\begin{array}{c}\text { Active } \\
\text { ingredient } \\
\mathrm{K}_{2} \mathrm{O}\end{array}$} & \multicolumn{2}{|c|}{$\begin{array}{l}\text { Fertilizer: } \\
\text { Potassium } \\
\text { sulfate }(50 \%) \\
\end{array}$} & \multicolumn{2}{|c|}{$\begin{array}{c}\text { Active } \\
\text { ingredient } \\
\mathrm{K}_{2} \mathrm{O} \\
\end{array}$} & \multicolumn{2}{|c|}{$\begin{array}{c}\text { Fertilizer: } \\
\text { Potassium } \\
\text { chloride }(60 \%)\end{array}$} & \multicolumn{2}{|c|}{$\begin{array}{c}\text { Active } \\
\text { ingredient } \\
\mathrm{K}_{2} \mathrm{O} \\
\end{array}$} & \multicolumn{2}{|c|}{$\begin{array}{l}\text { Fertilizer: } \\
\text { Patent káli } \\
(30+10 \%)\end{array}$} & \multicolumn{2}{|c|}{$\begin{array}{l}\text { Applied } \mathrm{Mg} \\
\text { active } \\
\text { ingredient }\end{array}$} \\
\hline & $\mathrm{kg} / \mathrm{ha}$ & $\mathrm{kg} / 50 \mathrm{~m}^{2}$ & $\mathrm{~kg} / \mathrm{ha}$ & $\mathrm{kg} / 50 \mathrm{~m}^{2}$ & $\mathrm{~kg} / \mathrm{ha}$ & $\mathrm{kg} / 50 \mathrm{~m}^{2}$ & $\mathrm{~kg} / \mathrm{ha}$ & $\mathrm{kg} / 50 \mathrm{~m}^{2}$ & $\mathrm{~kg} / \mathrm{ha}$ & $\mathrm{kg} / 50 \mathrm{~m}^{2}$ & $\mathrm{~kg} / \mathrm{ha}$ & $\mathrm{kg} / 50 \mathrm{~m}^{2}$ & $\mathrm{~kg} / \mathrm{ha}$ & $\mathrm{kg} / 50 \mathrm{~m}^{2}$ \\
\hline 1 & 0 & 0 & 0 & 0 & - & - & - & - & - & - & - & - & - & - \\
\hline 2 & - & - & - & - & 80 & 0.4 & 133 & 0.66 & - & - & - & - & - & - \\
\hline 3 & - & - & - & - & 160 & 0.8 & 266 & 1.32 & - & - & - & - & - & - \\
\hline 4 & - & - & - & - & 240 & 1.2 & 399 & 1.98 & - & - & - & - & - & - \\
\hline 5 & 80 & 0.4 & 160 & 0.8 & - & - & - & - & - & - & - & - & - & - \\
\hline 6 & 160 & 0.8 & 320 & 1.6 & - & - & - & - & - & - & - & - & - & - \\
\hline 7 & 240 & 1.2 & 480 & 2.4 & - & - & - & - & - & - & - & - & - & - \\
\hline 8 & - & - & - & - & - & - & - & - & 80 & 0.4 & 267 & 1.33 & 26.7 & 0.13 \\
\hline 9 & - & - & - & - & - & - & - & - & 160 & 0.8 & 534 & 2.66 & 53.4 & 0.26 \\
\hline 10 & - & - & - & - & - & - & - & - & 240 & 1.2 & 801 & 3.99 & 80.1 & 0.39 \\
\hline
\end{tabular}

reduced, which can easily form due to the mechanical stress of tubers. Different studies verified that with increasing potassium content, the resistance of potato to after-cooking darkening also improves. If the potassium content of the tuber exceeds $2.5 \%$, such colorations hardly occur. (Loch et al., 1993).

In the experiments of Kruppa (1999) on acidic, Mgdeficient humus sandy soil (1996-1998), K-, Ca-, and Mg fertilizer treatments resulted in a significant yield increment. In addition to the necessary $\mathrm{N}$ and $\mathrm{P}$ fertilizers, he recommended to apply a $30 \%$ dosage of $\mathrm{CaCO}_{3}(1.5 \mathrm{t} / \mathrm{ha})$ directly under the forecrop (triticale) or 60-90\% dosage of $\mathrm{CaCO}_{3}(3-4.5 \mathrm{t} / \mathrm{ha}) 3-4$ years before in order to achieve a potato yield of $25-30 \mathrm{t} / \mathrm{ha}$. In order to obtain an optimum yield, he advises to apply $180-200 \mathrm{~kg} / \mathrm{ha} \mathrm{K}_{2} \mathrm{O}$ and $45-50 \mathrm{~kg} / \mathrm{ha} \mathrm{Mg}$ on $\mathrm{Mg}$-deficient acidic sandy soils. As a result of the treatments the number of tubers in the size category $45 \mathrm{~mm}<$ increased significantly. The coloration of tubers decreased due to the effect of the $\mathrm{Ca}, \mathrm{K}, \mathrm{Mg}$ treatments. The $\mathrm{Ca}, \mathrm{K}, \mathrm{Mg}$ fertilizers gave the best results regarding yield quality and quantity when applied together.

Potato is highly sensitive to the lack of magnesium. By magnesium fertilization (80-90 kg/ha crystal magnesiumsulfate), a $20-25 \%$ yield increment can be achieved (Bocz, 1996). Since potato is usually grown mostly on light, generally magnesium-deficient soils, the application of 30 $\mathrm{kg} / \mathrm{ha} \mathrm{Mg}$ active ingredient is recommended in these areas. In the case of magnesium deficiency, the dry matter and starch contents are reduced (Loch et al., 1993).

By performing the suggested potassium (160-240 kg K active ingredient) and magnesium fertilizer treatments (80-120 kg Mg active ingredient) a yield increment of

\section{Materials and methods}

The experiment series was started at Kisvárda in 1998, then it was continued at Tornyospálca from 2000 after a oneyear break. In all five years $(1998,2000,2001,2002,2003)$, the impact of three types of potassium fertilizers (potassium chloride, potassium sulfate and Patentkáli) in three dosages $\left(80,160,240 \mathrm{~kg} / \mathrm{ha} \mathrm{K}_{2} \mathrm{O}\right)$ was studied on brown forest soils with the same $\mathrm{N}$ and $\mathrm{P}$ supply on $50 \mathrm{~m}^{2}$ parcels in nonirrigated experiments with 3 and 4 replicates. The control was treated with $\mathrm{N}$ and $\mathrm{P}$ (Tables 1 and 2 )

The test plant was cultivar Desirée, Kondor, Agria and Pannónia in 1998 and 2000, 2001, 2002 and 2003, respectively. The obtained yields were analyzed by an analysis of variance (Sváb, 1981).

\section{Results and discussion}

\section{Results of the experiment in 1998}

The significantly highest yields were obtained in decreasing order in treatments $9\left(160 \mathrm{~kg} / \mathrm{ha} \mathrm{K} \mathrm{K}_{2} \mathrm{O}\right.$ applied as Patentkáli containing also $53.4 \mathrm{~kg} / \mathrm{ha} \mathrm{MgO}), 4\left(240 \mathrm{~kg} / \mathrm{ha} \mathrm{K}_{2} \mathrm{O}\right.$ in the form of potassium chloride $)$ and $10\left(240 \mathrm{~kg} / \mathrm{ha} \mathrm{K}_{2} \mathrm{O}\right.$ applied as Patentkáli containing also $80.1 \mathrm{~kg} / \mathrm{ha} \mathrm{MgO}$ ) (Table 3).

No clear relationships were found between raw and after boiling colorations and the treatments. Based on the examinations, dry matter content was the highest in the tubers from the control treatment. The largest amount of 
starch could be found in the tubers from treatments 9 and 7 . The highest potassium content was measured in tubers from treatments $6,7,8,9,10$.

The highest magnesium content was detected in tubers from treatments 6 and 10 .

Table 3. Yields in the different treatments (t/ha), Kisvárda, 1998

\begin{tabular}{|l|c|}
\hline Treatment & Yield (t/ha) \\
\hline 1. Control & 24.80 \\
\hline 2. $\mathrm{KCl} 80 \mathrm{~kg} / \mathrm{ha}$ & 27.10 \\
\hline 3. $\mathrm{KCl} 160 \mathrm{~kg} / \mathrm{ha}$ & 23.05 \\
\hline 4. $\mathrm{KCl} 240 \mathrm{~kg} / \mathrm{ha}$ & 30.20 \\
\hline $5 . \mathrm{K}_{2} \mathrm{SO}_{4} 80 \mathrm{~kg} / \mathrm{ha}$ & 25.48 \\
\hline 6. $\mathrm{K}_{2} \mathrm{SO}_{4} 160 \mathrm{~kg} / \mathrm{ha}$ & 24.18 \\
\hline 7. $\mathrm{K}_{2} \mathrm{SO}_{4} 240 \mathrm{~kg} / \mathrm{ha}$ & 26.23 \\
\hline 8. Patentkáli $80 \mathrm{~kg} / \mathrm{ha}$ & 24.74 \\
\hline 9. Patentkáli $160 \mathrm{~kg} / \mathrm{ha}$ & 31.06 \\
\hline 10. Patentkáli $240 \mathrm{~kg} / \mathrm{ha}$ & 30.06 \\
\hline SD $5 \%$ & $\mathbf{2 . 9 0 2}$ \\
\hline
\end{tabular}

\section{Results of the experiment in 2000}

The significantly highest yield compared to the control (treatment 1) was obtained in treatment $7\left(240 \mathrm{~kg} / \mathrm{ha} \mathrm{K} \mathrm{KO}_{4}\right)$ (Table 4).

Significantly high yields were obtained in treatments 10 (240 kg/ha $\mathrm{K}_{2} \mathrm{O}$ active ingredient, Patentkáli) and 4 (240 kg/ha $\mathrm{K}_{2} \mathrm{O}$ applied in the form of potassium chloride). There was no significant difference in yields between the high-dosage application of potassium sulfate and Patentkáli (240 kg/ha). Except for treatments $2(80 \mathrm{~kg} / \mathrm{ha} \mathrm{KCl})$ and $5(80 \mathrm{~kg} / \mathrm{ha}$ $\mathrm{K}_{2} \mathrm{SO}_{4}$ ), all treatments significantly increased potato yields.

Table 4. Yields in the different treatments (t/ha), Tornyospálca, 2000

\begin{tabular}{|l|c|}
\hline Treatment & Yield (t/ha) \\
\hline 1. Control & 15.30 \\
\hline 2. KCL $80 \mathrm{~kg} / \mathrm{ha}$ & 16.15 \\
\hline 3. KCL $160 \mathrm{~kg} / \mathrm{ha}$ & 16.95 \\
\hline 4. KCL $240 \mathrm{~kg} / \mathrm{ha}$ & 18.43 \\
\hline 5. $\mathrm{K}_{2} \mathrm{SO}_{4} 80 \mathrm{~kg} / \mathrm{ha}$ & 16.25 \\
\hline 6. $\mathrm{K}_{2} \mathrm{SO}_{4} 160 \mathrm{~kg} / \mathrm{ha}$ & 17.88 \\
\hline 7. $\mathrm{K}_{2} \mathrm{SO}_{4} 240 \mathrm{~kg} / \mathrm{ha}$ & 20.20 \\
\hline 8. Patentkáli $80 \mathrm{~kg} / \mathrm{ha}$ & 16.73 \\
\hline 9. Patentkáli $160 \mathrm{~kg} / \mathrm{ha}$ & 18.58 \\
\hline 10. Patentkáli $240 \mathrm{~kg} / \mathrm{ha}$ & 19.90 \\
\hline SD $5 \%$ & 1.022 \\
\hline
\end{tabular}

\section{Results of the experiment in 2001}

The significantly highest yield (as compared to the control and the other treatments) was obtained in treatment 10 (240 kg/ha Patentkáli) (Table 5). Yield of the treatment with $240 \mathrm{~kg} / \mathrm{ha}$ Patentkáli (treatment 10) was significantly higher than the second largest yield of the treatment with $240 \mathrm{~kg} /$ ha potassium sulfate (treatment 7 ) and the yield of the
Table 5. Yields in the different treatments (t/ha), Tornyospálca, 2001

\begin{tabular}{|l|c|}
\hline Treatment & Yield (t/ha) \\
\hline 1. Control & 42.4 \\
\hline 2. $\mathrm{KCL} 80 \mathrm{~kg} / \mathrm{ha}$ & 44.1 \\
\hline 3. $\mathrm{KCL} 160 \mathrm{~kg} / \mathrm{ha}$ & 45.4 \\
\hline 4. $\mathrm{KCL} 240 \mathrm{~kg} / \mathrm{ha}$ & 47.3 \\
\hline $5 . \mathrm{K}_{2} \mathrm{SO}_{4} 80 \mathrm{~kg} / \mathrm{ha}$ & 46.3 \\
\hline 6. $\mathrm{K}_{2} \mathrm{SO}_{4} 160 \mathrm{~kg} / \mathrm{ha}$ & 49.7 \\
\hline 7. $\mathrm{K}_{2} \mathrm{SO}_{4} 240 \mathrm{~kg} / \mathrm{ha}$ & 52.4 \\
\hline 8. Patentkaili $80 \mathrm{~kg} / \mathrm{ha}$ & 50.3 \\
\hline 9. Patentkáli $160 \mathrm{~kg} / \mathrm{ha}$ & 51.5 \\
\hline 10. Patentkáli $240 \mathrm{~kg} / \mathrm{ha}$ & 55.3 \\
\hline SD $5 \%$ & 1.821 \\
\hline
\end{tabular}

treatment with $240 \mathrm{~kg} / \mathrm{ha}$ potassium chloride (treatment 4). Except for treatment $2(80 \mathrm{~kg} / \mathrm{ha} \mathrm{KCl})$, all treatment significantly increased the potato yield.

\section{Results in 2002}

In Table 6, it can be seen that the significantly highest yield was obtained in treatment 9 with $160 \mathrm{~kg} / \mathrm{ha} \mathrm{K}+53.4$ $\mathrm{kg} / \mathrm{ha} \mathrm{Mg}$ active ingredients, i.e. with $534 \mathrm{~kg} / \mathrm{ha}$ Patentkáli.

Table 6. Yields of the different treatments (t/ha), Tornyospálca, 2002

\begin{tabular}{|l|c|}
\hline Treatment & Yield (t/ha) \\
\hline 1. Control & 20.77 \\
\hline $2 . \mathrm{KCL} 80 \mathrm{~kg} / \mathrm{ha}$ & 21.30 \\
\hline $3 . \mathrm{KCL} 160 \mathrm{~kg} / \mathrm{ha}$ & 24.35 \\
\hline $4 . \mathrm{KCL} 240 \mathrm{~kg} / \mathrm{ha}$ & 25.78 \\
\hline $5 . \mathrm{K}_{2} \mathrm{SO}_{4} 80 \mathrm{~kg} / \mathrm{ha}$ & 22.27 \\
\hline $6 . \mathrm{K}_{2} \mathrm{SO}_{4} 160 \mathrm{~kg} / \mathrm{ha}$ & 21.77 \\
\hline $7 . \mathrm{K}_{2} \mathrm{SO}_{4} 240 \mathrm{~kg} / \mathrm{ha}$ & 25.70 \\
\hline $8 . \mathrm{Patentkali} 80 \mathrm{~kg} / \mathrm{ha}$ & 26.05 \\
\hline 9. Patentkáli $160 \mathrm{~kg} / \mathrm{ha}$ & 31.45 \\
\hline 10. Patentkáli $240 \mathrm{~kg} / \mathrm{ha}$ & 30.88 \\
\hline SD5\% & $\mathbf{0 . 6 1 9}$ \\
\hline
\end{tabular}

The second largest yield, not significantly smaller than the previous one was obtained in treatment 10 with $240 \mathrm{~kg} / \mathrm{ha} \mathrm{K}$ $+80.1 \mathrm{~kg} / \mathrm{ha} \mathrm{Mg}$ active ingredients, i.e. with $801 \mathrm{~kg} / \mathrm{ha}$

Table 7. Yields in the different treatments (t/ha), Tornyospálca, 2003

\begin{tabular}{|l|c|}
\hline Treatment & Yield (t/ha) \\
\hline 1. Control & 15.4 \\
\hline $2 . \mathrm{KCL} 80 \mathrm{~kg} / \mathrm{ha}$ & 15.9 \\
\hline $3 . \mathrm{KCL} 160 \mathrm{~kg} / \mathrm{ha}$ & 15.7 \\
\hline $4 . \mathrm{KCL} 240 \mathrm{~kg} / \mathrm{ha}$ & 15.7 \\
\hline $5 . \mathrm{K}_{2} \mathrm{SO}_{4} 80 \mathrm{~kg} / \mathrm{ha}$ & 17.3 \\
\hline $6 . \mathrm{K}_{2} \mathrm{SO}_{4} 160 \mathrm{~kg} / \mathrm{ha}$ & 15.9 \\
\hline $7 . \mathrm{K}_{2} \mathrm{SO}_{4} 240 \mathrm{~kg} / \mathrm{ha}$ & 15.1 \\
\hline $8 . \mathrm{Patentkáli} 80 \mathrm{~kg} / \mathrm{ha}^{2}$ Patentkáli $160 \mathrm{~kg} / \mathrm{ha}$ & 16.3 \\
\hline 10. Patentkáli $240 \mathrm{~kg} / \mathrm{ha}$ & 17.7 \\
\hline SD5\% & 16.5 \\
\hline
\end{tabular}


Table 8. Annual and five-year mean yields of the experiment between 1998 and 2003

\begin{tabular}{|l|c|c|c|c|c|c|c|}
\hline Treatment & $\mathbf{1 9 9 8} \mathbf{t / h a}$ & $\mathbf{2 0 0 1} \mathbf{t} / \mathbf{h a}$ & $\mathbf{2 0 0 1} \mathbf{t} / \mathbf{h a}$ & $\mathbf{2 0 0 2} \mathbf{t} / \mathbf{h a}$ & $\mathbf{2 0 0 3}$ t/ha & Mean t/ha & Yield \% \\
\hline 1. Centrol & 24.80 & 15.30 & 42.40 & 20.77 & 15.40 & 23.73 & 100.0 \\
\hline 2. $\mathrm{KCL} 80 \mathrm{~kg} / \mathrm{ha}$ & 27.10 & 16.15 & 44.10 & 21.30 & 15.90 & 24.91 & 105.0 \\
\hline $3 . \mathrm{KCL} 160 \mathrm{~kg} / \mathrm{ha}$ & 23.05 & 16.95 & 45.40 & 24.35 & 15.70 & 25.09 & 105.7 \\
\hline $4 . \mathrm{KCL} 240 \mathrm{~kg} / \mathrm{ha}$ & 30.20 & 18.43 & 47.30 & 25.78 & 15.70 & 27.48 & 115.8 \\
\hline $5 . \mathrm{K}_{2} \mathrm{SO}_{4} 80 \mathrm{~kg} / \mathrm{ha}$ & 25.48 & 16.25 & 46.30 & 22.27 & 17.30 & 25.52 & 107.5 \\
\hline 6. $\mathrm{K}_{2} \mathrm{SO}_{4} 160 \mathrm{~kg} / \mathrm{ha}$ & 24.18 & 17.88 & 49.70 & 21.77 & 15.90 & 25.89 & 109.1 \\
\hline 7. $\mathrm{K}_{2} \mathrm{SO}_{4} 240 \mathrm{~kg} / \mathrm{ha}$ & 26.23 & 20.20 & 52.40 & 25.70 & 15.10 & 27.93 & 117.7 \\
\hline 8. Patentkáli $80 \mathrm{~kg} / \mathrm{ha}$ & 24.74 & 16.73 & 50.30 & 26.05 & 16.30 & 26.82 & 113.0 \\
\hline 9. Patentkáli $\mathbf{1 6 0} \mathrm{kg} / \mathrm{ha}$ & $\mathbf{3 1 . 0 6}$ & $\mathbf{1 8 . 5 8}$ & $\mathbf{5 1 . 5 0}$ & $\mathbf{3 1 . 4 5}$ & $\mathbf{1 7 . 7 0}$ & $\mathbf{3 0 . 1 0}$ & 126.8 \\
\hline 10. Patentkáli $240 \mathrm{~kg} / \mathrm{ha}$ & 30.06 & 19.90 & 55.30 & 30.88 & 16.50 & 30.53 & 128.7 \\
\hline SD5\% & 2.902 & 1.022 & 1.821 & 0.619 & $\mathbf{6 . 9 3 4}$ & 2.660 & 11.21 \\
\hline
\end{tabular}

Patentkáli. These treatments (9 and 10) resulted in a significantly higher yield as compared to the control (treatment 1) and all the other treatments.

\section{Results in 2003}

As presented in Table 7, very low yields were obtained in 2003 due to the extreme draught and there were only small, not significant differences between the yields.

\section{Complex evaluation of the potassium fertilization experiment between 1998 and 2003}

The combined results of the experiment are shown in Table 8.

Based on the five-year mean yield data, most significantly highest yields were obtained in treatment 10 with $240 \mathrm{~kg} / \mathrm{ha}$ Patentkáli. It was followed in decreasing order by the (not significantly) lower yields of treatments 9 with $160 \mathrm{~kg} / \mathrm{ha}$ Patentkáli and 7 with $240 \mathrm{~kg} / \mathrm{ha} \mathrm{K} 2 \mathrm{SO} 4$. All these three treatments had a significantly higher yield than that of the N, P control (treatment 1) and treatments 2 (80 $\mathrm{kg} / \mathrm{ha} \mathrm{KCl})$ and $3(160 \mathrm{~kg} / \mathrm{ha} \mathrm{KCl})$. The results also show that treatment $4(240 \mathrm{~kg} / \mathrm{ha} \mathrm{KCl})$ also had a significantly higher yield than that of the control, but this yield was significantly lower than in treatment $10(240 \mathrm{~kg} /$ ha Patentkáli). It can be concluded that the potassium chloride fertilizer $(\mathrm{KCl})$ was the least effective as regards yields and Patentkáli proved to be the most effective fertilizer, the yields obtained in Patentkáli treatments were higher in all cases than yields of treatments with $\mathrm{KCl}$ and potassium sulfate with the same $\mathrm{K} 2 \mathrm{O}$ active ingredient dosage. The difference was obviously caused by the $10 \% \mathrm{Mg}$ active ingredient content of Patentkáli, yields of Patentkáli treatments were 5.5-17.7\% higher than those of potassium sulfate treatments with the same amount of $\mathrm{K}$ active ingredient (expressed as $\mathrm{K}_{2} \mathrm{O}$ ). The highest significant difference $(17.7 \%)$ was measured between treatments of Patentkáli and potassium sulfate with dosages of $160 \mathrm{~kg} / \mathrm{ha}$.

\section{References}

Bocz, E. (1996): Burgonya. In: Szántóföldi növénytermesztés. Szerk: Bocz et al. Mezögazda kiadó, Budapest 574-611.p.

Glas, K. Orvolvius, K. Terbe, I., Fodor, Z. (1997): A termésmennyiség, a termésminöség, valamint a kálium mütrágyázás összefüggése a burgonyatermesztésben. Új Kertgazdaság. 1: 82-86.

Kruppa, J. (1997): A nyirségi burgonyatermesztés gyakorlati kézikönyve. Budapest. USAID ACDI/VOCA 85.

Kruppa, J. (1999): A burgonya és termesztése I-IV. Agroinform Kiadó, Budapest.

Kruppa, J. (1999): A burgonya K-, Ca- és Mg-trágyázása savanyú humuszos homoktalajon. Mag Kutatás, Termesztés, Kereskedelem. $12(2): 20-23$.

Loch, J., Pethö, F., Vágó, I., Kaspar, G., Andres, E. (1993): Burgonya. In: Kálium termésbiztonság és jó minöség. Szerk: Andres, E. International Potash Institute Research Topics 15: 25-26.

Pocsai, K. (2001): A burgonya tápanyag és vizgazdálkodása. Burgonyatermesztés. 1: 17-22.

Sváb, J. (1981): Biometriai módszerek a kutatásban. Mezögazdasági Kiadó, Budapest.

Terbe, I. (2000): A hajtatott burgonya trágyázása. Burgonyatermesztés. $4:$ 39-40. 